\title{
Six-Membered N-Heterocyclic Carbenes with a 1,1'-Ferrocenediyl Backbone: Bulky Ligands with Strong Electron-Donor Capacity and Unusual Non-Innocent Character
}

\author{
Ulrich Siemeling, ${ }^{*[a]}$ Christian Färber, ${ }^{\text {|a| }}$ Michael Leibold, ${ }^{\text {|al }}$ Clemens Bruhn, ${ }^{\text {[a] }}$ \\ Philipp Mücke, ${ }^{[b]}$ Rainer F. Winter, ${ }^{[b]}$ Biprajit Sarkar, ${ }^{[c]}$ Moritz von Hopffgarten, ${ }^{[d]}$ and \\ Gernot Frenking ${ }^{[d]}$
}

\author{
Keywords: Carbenes / N-Heterocyclic carbenes / Radicals / Density-functional calculation / Ligand effects / Redox chemis- \\ try / Sandwich complexes
}

The stable, crystalline N-heterocyclic diaminocarbene fc $\left[\mathrm{N}\left(\mathrm{CH}_{2} t \mathrm{Bu}\right)-\mathrm{C}-\mathrm{N}\left(\mathrm{CH}_{2} t \mathrm{Bu}\right)\right]\left(\mathbf{2 d}, \mathrm{fc}=1,1^{\prime}\right.$-ferrocenediyl) was prepared by deprotonation of its formamidinium precursor $\mathrm{fc}\left[\mathrm{N}\left(\mathrm{CH}_{2} t \mathrm{Bu}\right)-\mathrm{CH}-\mathrm{N}\left(\mathrm{CH}_{2} t \mathrm{Bu}\right)\right]\left[\mathrm{BF}_{4}\right]$ (1d) and used for the preparation of the 16 valence electron complexes $[\mathrm{Mo}(\mathbf{2 d})$ $\left.(\mathrm{CO})_{4}\right], \quad[\mathrm{RhCl}(\mathbf{2 d})(\mathrm{cod})] \quad(\operatorname{cod}=1,5$-cyclooctadiene $)$ and $\left[\mathrm{RhCl}(\mathbf{2 d})(\mathrm{CO})_{2}\right] .1 \mathrm{~d}, \mathbf{2 d}$ and $[\mathrm{RhCl}(\mathbf{2 d})(\mathrm{cod})]$ were structurally characterised by single-crystal X-ray diffraction studies. The electrochemical properties of $\mathbf{2 d}$, its 2-adamantyl analogue 2c, its complex $\left[\mathrm{RhCl}(\mathbf{2 d})(\mathrm{CO})_{2}\right]$ and of the precursors $1 \mathbf{d}$ and 1,1'-bis(neopentylamino)ferrocene were investigated by electrochemistry. The carbenes are easily oxidised to the corresponding radical cation, whose persistent nature is unprecedented in the chemistry of $\mathrm{N}$-heterocyclic carbenes. The spin density is located at the Fe atom and the carbene $\mathrm{C}$ atom according to the results of EPR spectroscopic studies and DFT calculations.
The chemistry of $\mathrm{N}$-heterocyclic carbenes $(\mathrm{NHCs})^{[1]}$ has developed rapidly since Arduengo et al. described the first stable crystalline NHC, 1,3-di-1-adamantylimidazolin-2ylidene (IAd) ${ }^{[2]}$ in 1991. Based on pioneering work by the groups of Herrmann and Enders, ${ }^{[3]}$ they are widely applied as ligands in transition metal-catalysed reactions. ${ }^{[1 \mathrm{c}, l \mathrm{le}]}$ Their steric and electronic properties can be modified by the exocyclic substituents at the nitrogen atoms as well as by the backbone which connects the two nitrogen atoms. While five-membered NHCs based on imidazol, imidazolin and 1,2,4-triazol have received most attention so far, there is great current interest in "non-standard" NHCs, i.e. those with ring sizes other than five and/or with heteroatoms in the backbone. ${ }^{[4]}$ With a view to redox-tunable catalysts, ${ }^{[5]}$ we have focused our efforts on [3]ferrocenophane-type NHCs, where formally a d-block metal atom constitutes an integral part of a six-membered ring (Figure 1).

[a] Institut für Chemie, Universität Kassel, Heinrich-Plett-Str. 40, 34132 Kassel, Germany

[b] Institut für Anorganische Chemie, Universität Regensburg, Universitätsstr. 31, 93040 Regensburg, Germany

[c] Institut für Anorganische Chemie, Universität Stuttgart, Pfaffenwaldring 55, 70569 Stuttgart, Germany

[d] Fachbereich Chemie, Philipps-Universität Marburg, Hans-Meerwein-Str., 35032 Marburg, Germany

Supporting information for this article is available on the WWW under http://dx.doi.org/10.1002/ejic.200900863.

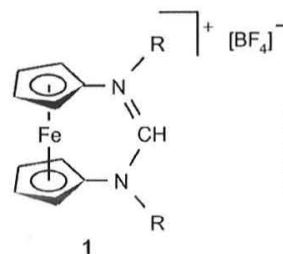

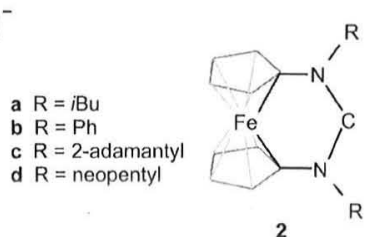

Figure 1. Structures of the ferrocene-based N-heterocyclic carbenes $\mathbf{2}$ and their formamidinium precursors $\mathbf{1 . 2}$ is drawn in a way that highlights the six-membered ring structure.

Independently from us, Bielawski and co-workers have also been addressing this system. They recently communicated the first two examples of such NHCs, generated in situ by deprotonation of the corresponding formamidinium tetrafluoroborates 1 (Figure 1). ${ }^{[6]} \mathbf{2 a}(\mathrm{R}=i \mathrm{Bu})$ and $\mathbf{2 b}(\mathrm{R}=$ $\mathrm{Ph}$ ) proved to be too unstable for isolation, and only $2 \mathrm{a}$ was sufficiently stable for NMR spectroscopic characterisation in solution. However, both could be trapped by coordination to $\left[\mathrm{RhCl}(\mathrm{L})_{2}\right]$ fragments. Electrochemical data proved to be in support of an electronic communication between the two metal centres in these Rh complexes, and throughspace $\pi$-backbonding between the Fe atom and the carbene $\mathrm{C}$ atom was invoked to be responsible for this.

By utilising bulkier substituents, we have been able to synthesise stable, isolable NHCs of this kind. This gives us the opportunity for a detailed investigation of the redox 
behaviour of such NHCs, which can shed more light on the nature of the interaction between the $\mathrm{Fe}$ atom and the carbene $\mathrm{C}$ atom. We note that studies addressing the redox chemistry of uncoordinated NHCs are scarce. Clyburne and co-workers have investigated two imidazolin-2-ylidene derivatives in this context. ${ }^{[7]}$ Irreversible oxidation was observed by cyclic voltammetry, while chemical oxidation with TCNE afforded results that agree with the formation of a transient radical cation intermediate. Enders et al. have described the reversible electrochemical reduction of a stable triazol-5-ylidene and characterised the resulting radical anion by EPR spectroscopy. ${ }^{[8]}$

We recently reported the preparation, isolation and structural characterisation of $2 \mathrm{c}(\mathrm{R}=2$-adamantyl) and its complexes $[\mathrm{RhCl}(2 \mathrm{c})(\mathrm{cod})]$ (cod $=1,5$-cyclooctadiene) and $\left[\mathrm{Mo}(2 \mathrm{c})(\mathrm{CO})_{4}\right] \cdot{ }^{\left[{ }^{[9]}\right.}$ We have now obtained the slightly less bulky neopentyl analogue ${ }^{[4 j]} \mathbf{2 d}$ by deprotonation of $\mathbf{1 d}$ with lithium diisopropylamide in $54 \%$ yield after standard workup (for experimental details, see the Supporting Information). Like its adamantyl analogue $2 \mathbf{c}, \mathbf{2 d}$ can be stored at room temperature in an inert atmosphere for months without noticeable decomposition. The ${ }^{13} \mathrm{C}$ NMR signal of the divalent carbon atom is observed at $\delta=268.1 \mathrm{ppm}$, which is close to the value of $260.7 \mathrm{ppm}$ found for $2 \mathrm{c} .^{[9]}$ While Bielawski and co-workers failed to obtain the formamidinium salt $\mathbf{1 d},{ }^{[6]}$ the synthesis of this NHC precursor from triethyl orthoformiate, ammonium tetrafluoroborate and 1,1'-bis(neopentylamino)ferrocene worked well in our hands. The structures of $\mathbf{1 d}$ and $\mathbf{2 d}$ were determined by single-crystal X-ray diffraction (Figures 2 and 3). In the case of $\mathbf{2 d}$, two independent molecules are present in the asymmetric unit, whose bond parameters are essentially identical.

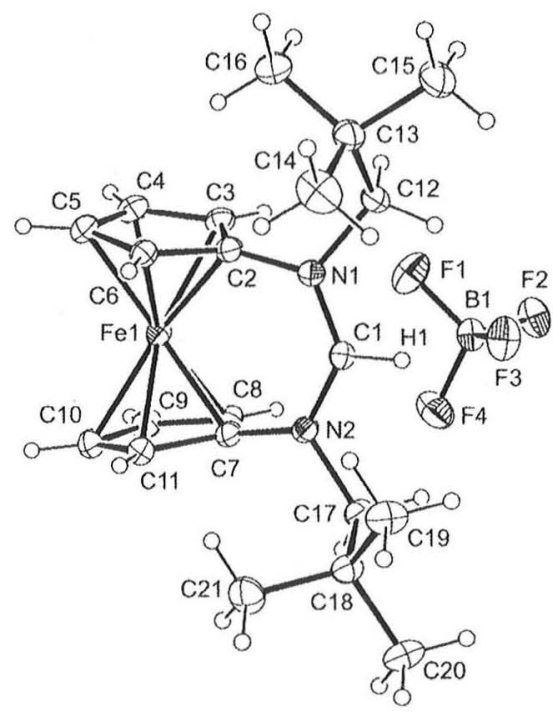

Figure 2. Molecular structure of $\mathbf{1 d}$ in the crystal.

The bonding environment of the $\mathrm{N}$ atoms is trigonal planar in each case. The N-C-N angle of $1 \mathbf{d}$ is $129.7(2)^{\circ}$, the $\mathrm{C}-\mathrm{N}$ bond lengths in this unit are ca. $1.33 \AA$, and the

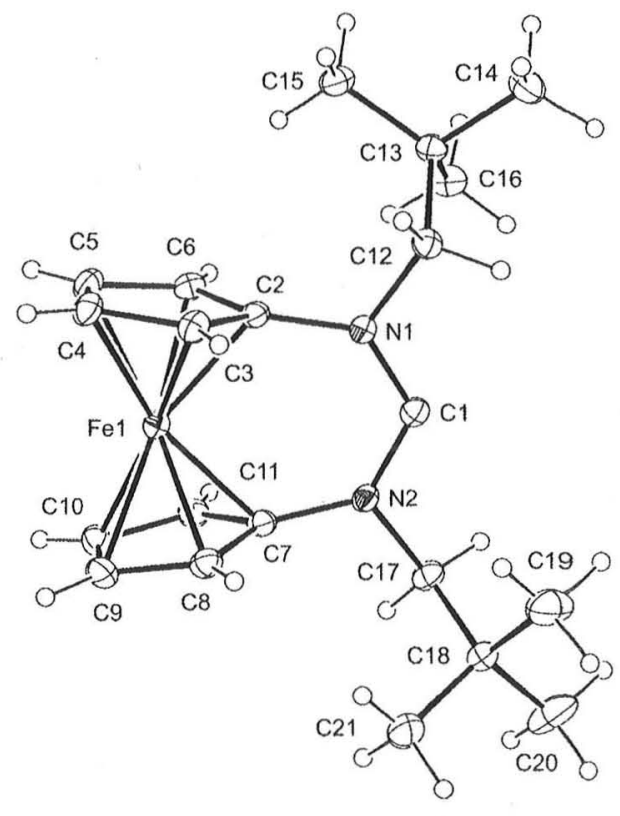

Figure 3. Molecular structure of $\mathbf{2 d}$ (one of the two independent molecules present in the asymmetric unit) in the crystal.

distance between the formamidinium carbon atom and the iron atom is ca. $3.31 \AA$. In the case of $\mathbf{2 d}$, the average N$\mathrm{C}-\mathrm{N}$ angle is ca. $120.5^{\circ}$, the $\mathrm{C}-\mathrm{N}$ bond lengths in this unit are ca. $1.36 \AA$ and the $\mathrm{Fe}-C_{\text {carbenc }}$ distance is ca. $3.44 \AA$. These values are similar to those observed for the 2-adamantyl analogues $\mathbf{1 c}$ and $\mathbf{2 c}$ and indicate a lower degree of $\pi$-delocalisation in the NHC as compared to the formamidinium precursor. ${ }^{[9]}$

The steric bulk of the neopentyl group present in $\mathbf{2} \mathbf{d}$ is intermediate between that of the 2-adamantyl group present in the stable NHC 2c and that of the isobutyl group present in $2 \mathrm{a}$, which turned out to be too unstable for isolation. We have started to study the coordination chemistry of $2 \mathbf{d}$ in order to compare its behaviour with that of these two analogues. The higher solubility of $\mathbf{2} \mathbf{d}$ and its complexes in comparison to that of $\mathbf{2 c}$ and its complexes was beneficial in this context, since it facilitated characterisation by ${ }^{13} \mathrm{C}$ NMR spectroscopy. In analogy to $\mathbf{2 a}$ and $\mathbf{2 c}$, the reaction of $2 d$ with $\left[\{\mathrm{Rh}(\mu-\mathrm{Cl})(\operatorname{cod})\}_{2}\right]$ proceeded smoothly and swiftly at room temperature, affording $[\mathrm{RhCl}(\mathbf{2 d})(\mathrm{cod})]$ in high yield. The carbene $\mathrm{C}$ atom gives rise to a doublet $\left({ }^{1} J_{\mathrm{Rh}-\mathrm{C}} 47.9 \mathrm{~Hz}\right)$ at $\delta=227.5 \mathrm{ppm}$ in the ${ }^{13} \mathrm{C}$ NMR spectrum. The product was structurally characterised by singlecrystal X-ray diffraction (Figure 4). The carbene $\mathrm{C}$ atom is in a trigonal planar environment (sum of angles ca. $360^{\circ}$ ). Its bond length to the $\mathrm{Rh}$ atom is $2.089(6) \AA$, which compares well with the corresponding values of 2.044(4), $2.059(4)$ and $2.088(10) \AA$ reported for $[\mathrm{RhCl}(2 \mathrm{a})(\mathrm{cod})],{ }^{[6]}$ $[\mathrm{RhCl}(2 \mathrm{~b})(\mathrm{cod})]^{[6]}$ and $[\mathrm{RhCl}(2 \mathrm{c})(\mathrm{cod})],{ }^{[9]}$ respectively. The $\mathrm{Fe}-C_{\text {carbenc }}$ distance is ca. $3.45 \AA$, which is close to the value of $3.43 \AA$ observed for its analogues containing $\mathbf{2 a - c}$.

Similar to $[\mathrm{RhCl}(\mathbf{2 a})(\mathrm{cod})]$ and $[\mathrm{RhCl}(\mathbf{2 b})(\mathrm{cod})],{ }^{[6]}$ $[\mathrm{RhCl}(\mathbf{2 d})(\mathrm{cod})]$ could be transformed into the corresponding carbonyl complex $\left[\mathrm{RhCl}(\mathbf{2 d})(\mathrm{CO})_{2}\right]$ quantitatively under 


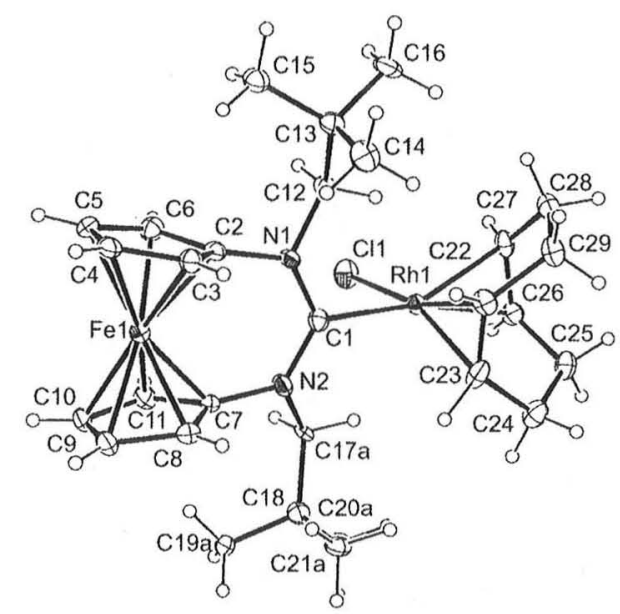

Figure 4. Molecular structure of $[\mathrm{RhCl}(2 \mathrm{~d})(\operatorname{cod})]$ in the crystal.

mild conditions (room temperature, ca. 1 atm $\mathrm{CO}$ ), while with $[\mathrm{RhCl}(\mathbf{2 c})(\mathrm{cod})]$ unreacted starting material was quantitatively recovered. The carbene $\mathrm{C}$ atom and the carbonyl $\mathrm{C}$ atoms give rise to doublets at $215.0\left({ }^{1} J_{\mathrm{Rh}-\mathrm{C}} 40.1 \mathrm{~Hz}\right)$, $186.4\left({ }^{1} J_{\mathrm{Rh}-\mathrm{C}} 54.7 \mathrm{~Hz}\right)$ and $184.0 \mathrm{ppm}\left({ }^{1} J_{\mathrm{Rh}-\mathrm{C}} 77.8 \mathrm{~Hz}\right)$, respectively, in the ${ }^{13} \mathrm{C}$ NMR spectrum. Two $v(\mathrm{CO})$ bands at 2072 and $1993 \mathrm{~cm}^{-1}\left[\mathrm{v}_{\mathrm{av}}(\mathrm{CO}) 2032.5 \mathrm{~cm}^{-1}\right]$ are present in the solid-state IR spectrum of this complex, which compares well to the values reported for dichloromethane solutions of $\left[\mathrm{RhCl}(2 \mathrm{a})(\mathrm{CO})_{2}\right]\left[2075\right.$ and $1995 \mathrm{~cm}^{-1}, v_{\mathrm{av}}(\mathrm{CO})$ $\left.2035 \mathrm{~cm}^{-1}\right]$ and $\left[\mathrm{RhCl}(\mathbf{2 b})(\mathrm{CO})_{2}\right]$ [2074 and $1994 \mathrm{~cm}^{-1}$, $\left.v_{\mathrm{av}}(\mathrm{CO}) 2034 \mathrm{~cm}^{-1}\right] \cdot{ }^{[6]}$ These values indicate that NHCs of type 2 exhibit an exceptionally strong electron donor capacity, higher than that of standard imidazolin-2-ylidene and imidazolidin-2-ylidene derivatives, but lower than that of six-membered NHCs with an all-carbon backbone. ${ }^{[10]}$

The reaction of $\mathbf{2 d}$ with $\left[\mathrm{Mo}(\mathrm{CO})_{4}(\mathrm{nbd})\right](\mathrm{nbd}=2,5$-norbornadiene) cleanly afforded the unusual 16 valence electron complex $\left[\mathrm{Mo}(\mathbf{2 d})(\mathrm{CO})_{4}\right]$. This behaviour is similar to that observed for the bulkier analogue $2 \mathrm{c}$. The carbene $\mathrm{C}$ atom gives rise to a ${ }^{13} \mathrm{C}$ NMR signal of fairly low intensity at $\delta=234.8 \mathrm{ppm}$, while two more pronounced low-field signals at $\delta=226.3$ and $209.4 \mathrm{ppm}$ (intensity ratio 1:1) are indicative of two inequivalent sets of $\mathrm{CO}$ ligands present in equal numbers. The IR spectrum of $\left[\mathrm{Mo}(\mathbf{2 d})(\mathrm{CO})_{4}\right]$ exhibits $v(C O)$ bands at 2029, 1900, 1880 and $1818 \mathrm{~cm}^{-1}$, which compares well with the values observed for the structurally characterised $\left[\mathrm{Mo}(\mathbf{2 c})(\mathrm{CO})_{4}\right] \quad(2025, \quad 1905,1876$ and $\left.1828 \mathrm{~cm}^{-1}\right)$. ${ }^{[9]}$ The formation of the 16 valence electron complexes $\left[\mathrm{Mo}(\mathrm{L})(\mathrm{CO})_{4}\right](\mathrm{L}=\mathbf{2 c}, 2 \mathrm{~d})$ demonstrates the exceptional steric bulk of these two NHC ligands. The only previous example of a related low-coordinate 16-valence- $\mathrm{e}^{-}$ NHC complex was reported by Nolan and co-workers, who unexpectedly obtained $\left[\mathrm{Ni}(\mathrm{IAd})(\mathrm{CO})_{2}\right]$ from the reaction of $\left[\mathrm{Ni}(\mathrm{CO})_{4}\right]$ with the bulky five-membered NHC IAd. ${ }^{\left[{ }^{1]}\right]} \mathrm{We}$ note that in the coordination chemistry of phosphanes isolable 16 valence electron molybdenum carbonyl complexes have only been obtained with at least two bulky phosphane ligands. ${ }^{[12]}$
The electrochemical properties of $\mathbf{2 c}, \mathbf{2 d},[\mathrm{RhCl}(\mathbf{2 d})$ $(\mathrm{CO})_{2}$ ] and of the precursors $\mathbf{1 d}$ and 1,1'-bis(neopentylamino)ferrocene have been investigated by electrochemistry. In their voltammograms the carbenes $\mathbf{2 c}$ and $\mathbf{2 d}$ and the complex [ $\left.\mathrm{RhCl}(2 \mathrm{~d})(\mathrm{CO})_{2}\right]\left\{\mathrm{CH}_{2} \mathrm{Cl}_{2} / 0.1 \mathrm{M}\left[\mathrm{NBu}_{4}\right]\left[\mathrm{PF}_{6}\right]\right.$ for 2c and $\left[\mathrm{RhCl}(\mathbf{2 d})(\mathrm{CO})_{2}\right], \mathrm{THF} /\left[\mathrm{NBu}_{4}\right]\left[\mathrm{PF}_{6}\right]$ for 2d, glassy carbon (GC) working electrode \} exhibit the same pattern of a chemically reversible (i.e., $i_{\mathrm{p}, \text { rev. }} / i_{\mathrm{p} \text {,forw. }}=1$ ), but electrochemically only quasi-reversible, one-electron oxidation wave which is followed by a partially reversible (2c) or irreversible $\left\{\mathbf{2 d},\left[\mathrm{RhCl}(\mathbf{2 d})(\mathrm{CO})_{2}\right]\right\}$ second oxidation at a more than $0.6 \mathrm{~V}$ higher potential (Figure 5). Quasireversibility arises from somewhat sluggish electron transfer kinetics as is evident from increasing differences of the halfwidths of the forward waves $E_{\mathrm{p}, \mathrm{f}}-E_{\mathrm{p}, \mathrm{f} / 2}$ and peak potential separations $\Delta E_{\mathrm{p}}$ when compared to the internal ferrocene standard with increasing sweep rate over the range from $25 \mathrm{mV} / \mathrm{s}$ to $1 \mathrm{~V} / \mathrm{s}$ and with decreasing temperature. Electron transfer kinetics of the second wave/peak tend to be even slower than those for the first one as follows from a further wave broadening with increasing sweep rate. These nonidealities were a particular problem on platinum electrodes, while glassy carbon electrodes performed better. Half-wave potentials $E_{1 / 2}{ }^{0 /+}$ for the first oxidations are $-0.415 \mathrm{~V}$ for $2 c,-0.42 \mathrm{~V}$ for $\mathbf{2 d}$, and $+0.44 \mathrm{~V}$ for $\left[\mathrm{RhCl}(2 \mathrm{~d})(\mathrm{CO})_{2}\right]$, while the second oxidation occurs at $E_{1 / 2}{ }^{+/ 2+}=+0.20 \mathrm{~V}$ for $2 \mathrm{c}$. We note that the irreversible oxidation of the imidazolin2-ylidene derivatives reported by Clyburne and co-workers occurred at $E_{\mathrm{p}} \approx-0.4 \mathrm{~V}$ vs. the same ferrocene/ferrocenium scale. ${ }^{[7]}$ Owing to the chemical irreversibility of the second oxidation step, only peak potentials can be provided for $\mathbf{2 d}$ and for $\left[\mathrm{RhCl}(\mathbf{2 d})(\mathrm{CO})_{2}\right]\left(E_{\mathrm{p}}=+0.46 \mathrm{~V}\right.$ and $+1.08 \mathrm{~V}$ at $v=$ $50 \mathrm{mV} / \mathrm{s}$, respectively). The neopentyl-substituted NHC 2d proved to be very moisture-sensitive and also reactive towards $\mathrm{CH}_{2} \mathrm{Cl}_{2}$. It has nevertheless been possible to determine its half-wave potential in the $\mathrm{CH}_{2} \mathrm{Cl}_{2} /\left[\mathrm{NBu}_{4}\right]\left[\mathrm{PF}_{6}\right]$ electrolyte system as $E_{1 / 2}{ }^{0 /+}=-0.405 \mathrm{~V}$ against the ferrocene/ferrocenium standard. Although the electrochemical cell was filled in a glove-box and maintained under a blanket of dried argon at positive pressure during the course of the measurements, small amounts of the hydrolysis product were observed in THF, which give rise to a weak anodic peak at ca. $-0.03 \mathrm{~V}$ (Figure 5, c). However, no growth of the wave of the hydrolysis product was observed during the experiments. This slight contamination, which is due to the remaining traces of water at the beginning of the experiment, should not affect the potentials of $\mathbf{2 d}$.

In order to determine the electron count for the first wave of the free ferrocene-based carbenes, the slopes of $i$ vs. $t^{-1 / 2}$ plots in chronoamperometry and the limiting currents in linear sweep voltammetry of $\mathbf{2 d}$ were compared to those of the decamethylferrocene standard under identical conditions according to the method described by Baranski et al. ${ }^{[13]}$ The value of $0.90( \pm 0.1)$ is slightly low but clearly establishes its one-electron nature. Proof that this wave is indeed an oxidation and not a reduction comes from the negative sign of the limiting current in linear sweep voltammetry and the fact that the cathodic baseline of the 

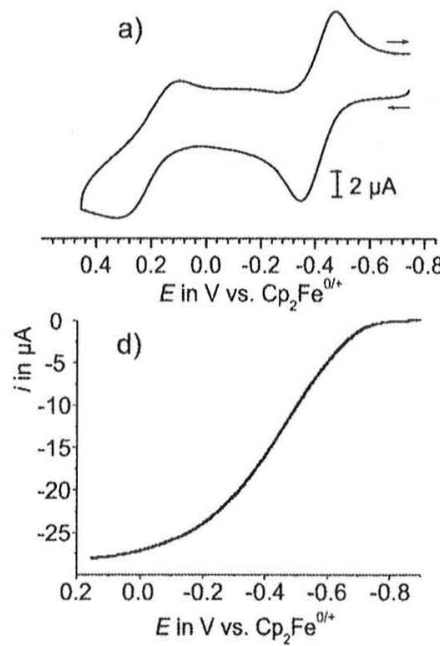

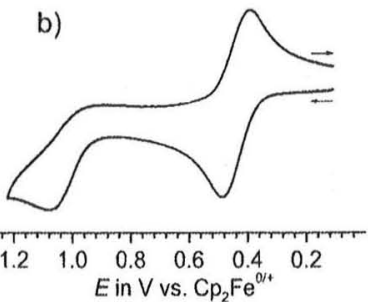

e)

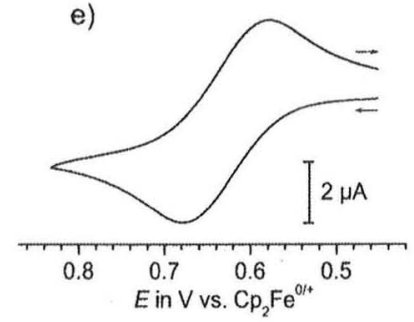

c)
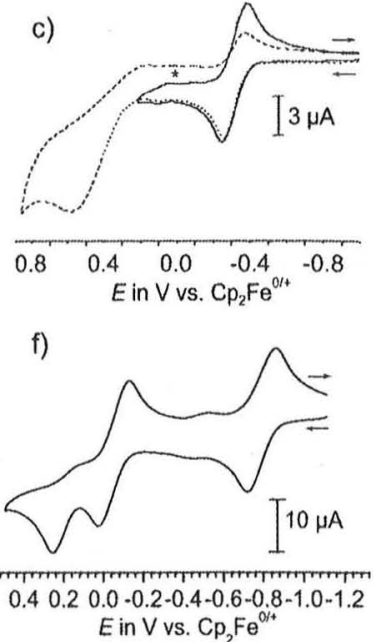

Figure 5. Voltammograms of a) $2 \mathrm{c}$ in $\mathrm{CH}_{2} \mathrm{Cl}_{2}$ at $v=100 \mathrm{mV} / \mathrm{s}$; b) $\left[\mathrm{RhCl}(\mathbf{2 d})(\mathrm{CO})_{2}\right.$ ] in $\mathrm{CH}_{2} \mathrm{Cl}_{2}$ at $v=100 \mathrm{mV} / \mathrm{s}$; c) $2 \mathrm{~d}$ in $\mathrm{THF}$ at $v=$ $25 \mathrm{mV} / \mathrm{s}$ (solid line: scan reversal after first wave, dashed line: scan reversal after second oxidation; the star symbol denotes traces of hydrolysis product formed inside the cell); d) linear sweep voltammetry of $\mathbf{2 d}$ in THF at a $33 \mu \mathrm{m} \mathrm{GC}$ electrode at $\nu=10 \mathrm{mV} / \mathrm{s}$; e) $1 \mathrm{~d}$ in $\mathrm{CH}_{2} \mathrm{Cl}_{2}, 0.1 \mathrm{M}\left[\mathrm{NBu}_{4}\right]\left[\mathrm{PF}_{6}\right]$ at $v=100 \mathrm{mV} / \mathrm{s} \mathrm{V} / \mathrm{s}$; f) 1,1'-bis(neopentylamino)ferrocene in THF at $v=50 \mathrm{mV} / \mathrm{s}$. All experiments were performed at room temperature and with $0.1 \mathrm{M}\left[\mathrm{NBu}_{4}\right]\left[\mathrm{PF}_{6}\right]$ as the supporting electrolyte.

$\mathbf{2 d} / 2 \mathbf{d}^{++}$couple approaches the limit of zero current (see Figure 5).

Precursor 1d is reversibly oxidised at $E_{1 / 2}=+0.630 \mathrm{~V}$ while $1,1^{\prime}$-bis(neopentylamino)ferrocene undergoes a reversible iron-centred oxidation at $-0.695 \mathrm{~V}$ in $\mathrm{CH}_{2} \mathrm{Cl}_{2}$ and at $-0.785 \mathrm{~V}$ in THF/0.1 м $\left[\mathrm{NBu}_{4}\right]\left[\mathrm{PF}_{6}\right]$. In the latter electrolyte, two additional consecutive oxidations of the amino substituents at $-0.045 \mathrm{~V}$ (reversible) and at $+0.355 \mathrm{~V}$ (irreversible, $E_{\mathrm{p}}$ at $0.1 \mathrm{~V} / \mathrm{s}$ ) are observed (Figure 5). The peak current ratio $i_{\mathrm{p}, \mathrm{f}(3)} / i_{\mathrm{p}, \mathrm{f}(2)}$ of the anodic peak currents for the third and second oxidations is invariant to sweep rate thus indicating that this wave arises from the third oxidation of the 1,1'-bis(neopentylamino)ferrocene rather than from degradation following the second oxidation.

Particularly astounding is the strong anodic shift of the first oxidation of $\mathbf{2 d}$ upon protonation $(1.035 \mathrm{~V})$ or upon coordination of the $\left[\mathrm{RhCl}(\mathrm{CO})_{2}\right]$ moiety to the carbene centre $(0.845 \mathrm{~V})$. The very negative half-wave potentials of the first oxidations of $\mathbf{2 c}$ and $\mathbf{2 d}$ and the strong anodic shifts upon blocking the carbene lone pair argue for a strong thermodynamic stabilisation of $2 \mathbf{c}^{++}$and $2 \mathbf{d}^{+}$, possibly by an intramolecular interaction between the carbene $\mathrm{C}$ atom and the $\mathrm{Fe}$ atom. However, it is unclear from the electrochemical data, whether the first oxidation occurs predominantly at the ferrocene moiety or at the carbene $\mathrm{C}$ atom.

To identify the site of electron removal we have applied EPR spectroscopy. Whereas oxidation of the carbene centre is expected to deliver a signal typical for organic radicals with very small $g$ anisotropy and average $g$ values close to the value of $g_{\mathrm{e}}=2.0023$ for the free electron, ${ }^{[14]}$ a ferrocenecentred oxidation would deliver a signal with very large $g$ anisotropy with one component appearing close to $g=4 .^{[15]}$ For the present cases, the species $2 \mathbf{c}^{\cdot+}$ and $2 \mathbf{d}^{++}$(electro- chemically generated in situ in $\left.\mathrm{CH}_{2} \mathrm{Cl}_{2} / 0.1 \mathrm{M}\left[\mathrm{NBu}_{4}\right]\left[\mathrm{PF}_{6}\right]\right)$ show signals with $g$ anisotropies $\left(\Delta g=g_{1}-g_{3}\right)$ of 0.467 and 0.615 , respectively, in frozen solution at $110 \mathrm{~K}$ (see the Supporting Information). The individual $g$ components are $g_{\|}=2.470$ and $g_{\perp}=2.003$ for $2 \mathrm{c}^{+}$and $g_{\|}=2.614$ and $g_{\perp}$ $=1.999$ for $2 \mathbf{d}^{++}$. These values point to a situation where the unpaired electron is delocalised over the molecule with substantial spin density on the ferrocene as well as the carbene part. ${ }^{[16]}$ The persistence of $\mathbf{2} \mathbf{c}^{\cdot+}$ and $\mathbf{2} \mathbf{d}^{++}$(chemically generated by oxidation with one equivalent of ferrocenium hexafluorophosphate) was checked by temperature-dependent EPR measurements. Both compounds showed essentially identical behaviour. Starting at a temperature of $110 \mathrm{~K}$, no loss of signal intensity was observed within $1 \mathrm{~h}$ in frozen solution at various higher temperatures up to the freezing point of the solution. When the oxidised species was subsequently left in fluid solution at $295 \mathrm{~K}$ for an additional period of $1 \mathrm{~h}$ and the spectrum was recorded again at $110 \mathrm{~K}$, this spectrum showed ca. $60 \%$ intensity compared to the spectrum recorded at the beginning of the experiment.

DFT calculations at the BP86/def2-SVP level which were performed for $2 \mathrm{e}^{++}(\mathrm{R}=\mathrm{Me})$ and $2 \mathrm{f}^{+}(\mathrm{R}=\mathrm{H})$ strongly support the delocalised nature of these radical cations (Figure 6, Table 1). In both cases the spin densities are mainly located at the $\mathrm{Fe}$ and the carbene $\mathrm{C}$ atom. Spin densities at other atoms are negligible. Note that according to the calculations the distribution of the spin density may significantly change for different groups $\mathrm{R}$ which is in agreement with the clearly different experimental $g$ components in $\mathbf{2} \mathbf{c}^{++}$ and $2 \mathbf{d}^{+}$. The optimised geometries for $2 \mathbf{e}^{++}$and $2 \mathbf{f}^{+}$, which comply quite well with the experimental values for $\mathbf{2} \mathbf{d}^{+}$, are given in the Supporting Information. 


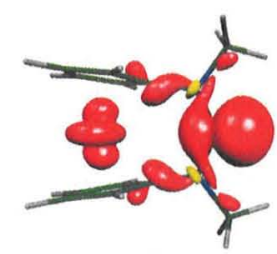

(a)

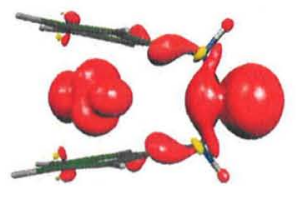

(b)
Figure 6. BP86/def2-SVP spin density of (a) $2 \mathrm{e}^{++}$and (b) $2 \mathbf{f}^{+}$. Red surfaces indicate regions of $\alpha$ density excess while regions with $\beta$ density excess are indicated by yellow surfaces.

Table 1. BP86/def2-SVP Mulliken spin densities of $2 \mathbf{e}^{++}$and $2 \mathbf{f}^{+}$.

\begin{tabular}{lcc}
\hline & $\mathbf{2 e}^{++}$ & $\mathbf{2 f}^{+}$ \\
\hline $\mathrm{Fe}$ & 0.29 & 0.47 \\
$\mathrm{C}_{\text {carbene }}$ & 0.68 & 0.54 \\
$\mathrm{~N}$ & -0.02 & -0.02 \\
$\mathrm{C}_{\mathrm{Cp}-\mathrm{N}}$ & 0.03 & 0.02 \\
\hline
\end{tabular}

In summary, we have demonstrated that ferrocene-based NHCs of type $\mathbf{2}$ are comparatively bulky redox-active ligands with very strong electron-donor capacity. They can be oxidised to the corresponding radical cations, whose long-lived nature is unprecedented in NHC chemistry. The spin density in these radical cations is located at the Fe atom and the carbene $\mathrm{C}$ atom. NHCs of type $\mathbf{2}$ represent a new subgroup of non-innocent ligands (NILs) ${ }^{[17]}$ based on ferrocene, since their redox activity rests not solely on the ferrocene nucleus. This adds an important new facet to the already rich chemistry of $\mathrm{N}$-heterocyclic carbenes and their complexes.

Supporting Information (see also the footnote on the first page of this article): Experimental details for the preparation of all new compounds (including spectroscopic and analytical data); crystallographic details for all structurally characterised compounds; experimental details for the electrochemical studies; EPR spectroscopic details (including figures showing EPR spectra of $2 \mathrm{c}^{\cdot+}$ and $2 \mathbf{d}^{++}$); computational details (including Cartesian coordinates of calculated minimum structures in tabular form and figures showing calculated minimum geometries).

\section{Acknowledgments}

We are grateful to the Deutsche Forschungsgemeinschaft (DFG) for generous funding and to the project students Ludmilla Gomer, Michael Kurlemann and Henry Memczak for their preparative help. Excellent service by the Hochschulrechenzentrum of the Philipps-University of Marburg (Germany) is gratefully acknowledged. Further computer time was provided by the Center for Scientific Computing of the Goethe University, Frankfurt/Main, Germany.

[1] For recent reviews, see: a) P. de Frémont, N. Marion, S. P. Nolan, Coord. Chem. Rev. 2009, 253, 862; b) F. E. Hahn, M. C. Jahnke, Angew. Chem. 2008, 120, 3166; Angew. Chem. Int. Ed. 2008, 47, 3122; c) $\mathrm{N}$-Heterocyclic Carbenes in Transition Metal Catalysis (Top. Organomet. Chem. 2007, 21) (Ed.: F. Glorius), Springer, Berlin, 2007; d) D. Enders, O. Niemeier, A. Henseler, Chem. Rev. 2007, 107, 5606; e) N-Heterocyclic Carbenes in Synthesis (Ed.: S. P. Nolan), Wiley-VCH, Weinheim, 2006; f) R. W. Alder, M. E. Blake, L. Chaker, J. N. Harvey, F. Paolini, J.
Schütz, Angew. Chem. 2004, 116, 6020; Angew. Chem. Int. Ed. 2004, 43, 5896; g) D. Enders, T. Balensiefer, Acc. Chem. Res. 2004, 37, 534; h) K. J. Cavell, D. S. McGuinness, Coord. Chem. Rev. 2004, 248, 671; i) V. César, S. Bellemin-Laponnaz, L. H. Gade, Chem. Soc. Rev. 2004, 33, 619; j) M. C. Perry, K. Burgess, Tetrahedron: Asymmetry 2003, 14, 951; k) E. Peris, R. H. Crabtree, C. R. Chim. 2003, 6, 33; 1) W. A. Herrmann, Angew. Chem. 2002, 114, 1342; Angew. Chem. Int. Ed. 2002, 41, 1290; m) D. Enders, H. Gielen, J. Organomet. Chem. 2001, 617-618, 70; n) D. Bourissou, O. Guerret, F. P. Gabbai, G. Bertrand, Chem. Rev. 2000, 100, 39.

[2] A. J. Arduengo III, R. L. Harlow, M. Kline, J. Am. Chem. Soc. $1991,113,361$.

[3] a) D. Enders, H. Gielen, G. Raabe, J. Runsink, J. H. Teles, Chem. Ber. 1996, 129, 1483; b) W. A. Herrmann, M. Elison, J. Fischer, C. Köcher, G. R. J. Artus, Angew. Chem. 1995, 107, 2602; Angew. Chem. Int. Ed. Engl. 1995, 34, 2371.

[4] See, for example: a) C. C. Scarborough, I. A. Guzei, S. S. Stahl, Dalton Trans. 2009, 2284; b) V. César, N. Lugan, G. Lavigne, J. Am. Chem. Soc. 2008, 130, 11286; c) M. Iglesias, D. J. Beetstra, J. C. Knight, L.-L. Ooi, A. Stasch, S. Coles, L. Male, M. B. Hursthouse, K. J. Cavell, A. Dervisi, I. A. Fallis, Organometallics 2008, 27, 3279; d) A. Kausamo, H. M. Tuononen, K. E. Krahulic, R. Roesler, Inorg. Chem. 2008, 47, 1145; e) P. Bazinet, T.-G. Ong, J. S. O'Brien, N. Lavoie, E. Bell, G. P. A. Yap, I. Korobkov, D. S. Richeson, Organometallics 2007, 26, 2885; f) T. D. Forster, K. E. Krahulic, H. M. Tuononen, R. McDonald, M. Parvez, R. Roesler, Angew. Chem. 2006, 118, 6504; Angew. Chem. Int. Ed. 2006, 45, 6356; g) C. Präsang, B. Donnadieu, G. Bertrand, J. Am. Chem. Soc. 2005, 127, 10182; h) K. E. Krahulic, G. D. Enright, M. Parvez, R. Roesler, J. Am. Chem. Soc. 2005, 127, 4142; i) C. C. Scarborough, M. J. W. Grady, I. A. Guzei, B. A. Gandhi, E. E. Bunel, S. S. Stahl, Angew. Chem. 2005, 117, 5403; Angew. Chem. Int. Ed. 2005, 44, 5269; j) C. C. Scarborough, B. V. Popp, I. A. Guzei, S. S. Stahl, J. Organomet. Chem. 2005, 690, 6143; k) E. Despagnet-Ayoub, R. H. Grubbs, J. Am. Chem. Soc. 2004, 126, 10198; 1) M. Mayr, K. Wurst, K.-H. Ongania, M. R. Buchmeiser, Chem. Eur. J. 2004, 10, 1256; m) P. Bazinet, G. P. A. Yap, D. S. Richeson, J. Am. Chem. Soc. 2003, 125, 13314; n) R. W. Alder, M. E. Blake, C. Bortolotti, S. Bufali, C. P. Butts, E. Linehan, J. M. Oliva, A. G. Orpen, M. J. Quayle, Chem. Commun. 1999, 241.

[5] See, for example: a) C. K. A. Gregson, V. C. Gibson, N. J. Long, E. L. Marshall, P. J. Oxford, A. J. P. White, J. Am. Chem. Soc. 2006, 128, 7410; b) U. Siemeling, R. R. Schrock, A. Stammler, H.-G. Stammler, O. Kuhnert, Z. Anorg. Allg. Chem. 2001, 627, 925; c) I. M. Lorkovic, R. R. Duff Jr., M. S. Wrighton, J. Am. Chem. Soc. 1995, 117, 3617.

[6] D. M. Khramov, E. L. Rosen, V. M. Lynch, C. W. Bielawski, Angew. Chem. 2008, 120, 2299; Angew. Chem. Int. Ed. 2008, 47, 2267.

[7] T. Ramnial, I. McKenzie, B. Gorodetzki, E. M. W. Tsang, J. A. C. Clyburne, Chem. Commun. 2004, 1054.

[8] D. Enders, K. Breuer, G. Raabe, J. Simonet, A. Ghanimi, H. B. Stegmann, J. H. Teles, Tetrahedron Lett. 1997, 38, 2833.

[9] U. Siemeling, C. Färber, C. Bruhn, Chem. Commun. 2009, 98.

[10] As a rule, the $v_{\text {av }}(\mathrm{CO})$ values determined for complexes of the type $\left[\mathrm{RhCl}(\mathrm{NHC})(\mathrm{CO})_{2}\right](\mathrm{NHC}=$ imidazolin-2-ylidene or imidazolidin-2-ylidene derivative with $\mathrm{R}$-substituted $\mathrm{N}$ atoms, abbreviated here as IR and SIR, respectively) lie above $2035 \mathrm{~cm}^{-1}$, as is shown by the following examples for $\mathrm{NHCl}$ $v_{\text {av }}(\mathrm{CO})\left[\mathrm{cm}^{-1}\right]$ : IMes/2038.5, SIMes/2040.5, see: a) S. Wolf, H. Plenio, J. Organomet. Chem. 2009, 694, 1487; Ii $\operatorname{Pr} / 2037.5$, see: b) G. D. Frey, C. F. Rentzsch, D. von Preysing, T. Scherg, M. Mühlhofer, E. Herdtweck, W. A. Herrmann, J. Organomet. Chem. 2006, 691, 5725; IMe/2041, see: c) W. A. Herrmann, M. Elison, J. Fischer, C. Köcher, G. R. J. Artus, Chem. Eur. J. 1996, 2, 772; SIMe/2047.5, SIiPr/2048.5, SIPh/2044.5, see: d) M. J. Doyle, M. F. Lappert, P. L. Pye, P. Terreros, J. Chem. Soc., Dalton Trans. 1984, 2355; $\mathrm{ICH}_{2} p$ Tol/2035.5, see: e) A. Bittermann, 
P. Härter, E. Herdtweck, S. D. Hoffmann, W. A. Herrmann, J. Organomet. Chem. 2008, 693, 2079; analogous complexes which contain a six-membered NHC ligand with an all-carbon backbone exhibit $v_{\text {av }}(\mathrm{CO})$ values $\leq 2031 \mathrm{~cm}^{-1}$, see ref. ${ }^{[4 \mathrm{c}, 4 \mathrm{k}, 41]}$ For comparison, the trialkylphosphane analogue $\left[\mathrm{RhCl}\left(\mathrm{PMe}_{3}\right)(\mathrm{CO})_{2}\right]$ has a $v_{\mathrm{av}}(\mathrm{CO})$ value of $2047 \mathrm{~cm}^{-1}$, see: $\left.\mathrm{f}\right)$ T. E. Bitterwolf, D. Lukmanova Kline, J. C. Linehan, C. R. Yonker, R. S. Addleman, Angew. Chem. 2001, 113, 2764; Angew. Chem. Int. Ed. 2001, 40, 2692.

[11] R. Dorta, E. D. Stevens, N. M. Scott, C. Costabile, L. Cavallo, C. D. Hoff, S. P. Nolan, J. Am. Chem. Soc. 2005, 127, 2485.

[12] For $\left[\mathrm{Mo}\left(\mathrm{PR}_{3}\right)_{2}(\mathrm{CO})_{3}\right](\mathrm{R}=t \mathrm{Bu}, \mathrm{Cy})$, see: a) S. P. Nolan, C. D. Hoff, J. Organomet. Chem. 1985, 290, 365; for $\left[\mathrm{Mo}\left({\left.\mathrm{P} i \mathrm{Pr}_{3}\right)_{2}-}^{-}\right.\right.$ $(\mathrm{CO})_{3}$ ], see: b) G. J. Kubas, J. Chem. Soc., Chem. Commun. 1980,61 .

[13] A. S. Baranski, W. R. Fawcett, C. M. Gilbert, Anal. Chem. $1985,57,166$

[14] W. Kaim, S. Ernst, V. Kasack, J. Am. Chem. Soc. 1990, 112, 173.
[15] C. Elschenbroich, E. Bilger, R. D. Ernst, D. R. Wilson, M. S. Kralik, Organometallics 1985, 4, 2068.

[16] J. A. Kramer, D. N. Hendrickson, Inorg. Chem. 1980, 19, 3330.

[17] For selected reviews concerning the coordination chemistry of NILs, see: a) W. Kaim, G. K. Lahiri, Angew. Chem. 2007, 119, 1808; Angew. Chem. Int. Ed. 2007, 46, 1778; b) K. E. Preuss, Dalton Trans. 2007, 2357; c) K. Ray, T. Petrenko, K. Wieghardt, F. Neese, Dalton Trans. 2007, 1552; d) E. Evangelio, D. Ruiz-Molina, Eur. J. Inorg. Chem. 2005, 2957; e) B. D. Koivisto, R. G. Hicks, Coord. Chem. Rev. 2005, 249, 2612; f) A. Vlček Jr., Coord. Chem. Rev. 2002, 230, 225; g) M. D. Ward, J. A. McCleverty, J. Chem. Soc., Dalton Trans. 2002, 275; h) P. Chaudhuri, K. Wieghardt, Prog. Inorg. Chem. 2001, 50, 151; i) A. M. Allgeier, C. A. Mirkin, Angew. Chem. 1998, 110, 936; Angew. Chem. Int. Ed. 1998, 37, 894; j) M. Fourmigué, Coord. Chem. Rev. 1998, 178-180, 823; k) W. Kaim, Coord. Chem. Rev. 1987, $76,187$. 